\title{
ЛАГЕРНЫЙ ЯЗЫК В ПЕРЕВОДЕ РОМАНА ОБИТЕЛЬ ЗАХАРА ПРИЛЕПИНА НА ПОЛЬСКИЙ ЯЗЫК
}

\section{Gulag's Slang in the Translation of Zakhar Prilepin's Novel "Abode" into the Polish Language}

Keywords: Gulag's slang, translation techniques, equivalence, adequacy

Contact: Uniwersytet Śląskiw Katowicach; abogusz94@gmail.com

Захар Прилепин является одним из самых популярных русских писателей XXI века. Хотя по образованию он - филолог, то до своего литературного дебюта в 2005 г. Прилепин был сотрудником ОМОН и принял участие в Первой чеченской и Дагестанской войнах. В 90-е гг. был связан с Националбольшевистской партией и ее преемницами. Военная и политическая деятельность Прилепина не прекратилась с началом литературной карьеры в последние годы он был советником Александра Захарченко - главы непризнанной международным обществом Донецкой Народной Республики. Кроме литературной и общественно-политической деятельности Прилепин занимается также музыкой (группа Элефанк), журналистикой, ведением авторской телепередачи Уроки русского, и др. (Borkowska 2019: 121-123).

Захар Прилепин стал известной фигурой культурного мира России благодаря своим прозаическим произведениям. Быстро завоевал книжный рынок России, получил признание как читателей, так и литературных критиков, о чем свидетельствует множество полученных Прилепиным наград («Большая книга», «Национальный бестселлер», «Ясная Поляна»). Его романы были переведены на многие языки, среди которых можно назвать: английский, немецкий, французский, испанский, итальянский, китайский, польский и чешский языки (Официальный сайт Захара Прилепина).

О популярности Прилепина свидетельствует также интерес, который оказывают его творчеству научные исследователи. Чаще всего его сочинения анализируются с литературоведческой точки зрения: предметом анализа становятся поэтика романов Прилепина и их отношения с другими 
произведениями. Переводы на другие языки практически не изучаются исследователями.

Один из новейших романов Захара Прилепина - Обитель (2014) - является очень интересным с точки зрения как языкознания, так и переводоведения. Так как его сюжет происходит в 1920-е гг. в Соловецком лагере, произведение изобилует разнообразием лексики: высоким стилем речи местных монахов, разговорной речью, диалектизмами и просторечием безграмотных зеков и воровским сленгом блатных - профессиональных преступников. Перевод Обители на польский язык осуществила Эва Роевска-Олеярчук.

Творчество Прилепина причисляется литературными критиками к т. наз. «новым реалистам», к которым принадлежат также Роман Сенчин и Сергей Шаргунов (Borkowska 2019: 126). Сяргей Падсасонны таким способом определяет одну из важнейших черт романа Обитель: «Писатель обращается к изображению жизни в Соловецком лагере особого назначения, совмещая историческую правду (воспоминания, свидетельства, документы, дневниковые записи, прототипы) с художественным вымыслом, что становится определяющей чертой поэтики произведения. При этом ряд исторических фактов искажены в романе, что отмечено в некоторых публикациях: начальник СЛОНа носил фамилию Эйхманс, а не ЭйхманИс, как в романе; он не был первым начальником, а пришел после Александра Ногтева - в романе наоборот, а также Эйхманс не являлся и создателем СЛОНа; комиссар Глеб Бокий перепутан с Борисом Бажановым, личным секретарем Сталина (...)» (Padsasonny 2018: 202).

Вторая из наиболее характерных черт стиля Прилепина - ссылки на другие произведения. В Обители писатель вступает в полемику с русской литературной традицией, прежде всего творчеством Федора Достоевского (Записки из Мертвого дома) и лагерной прозой Варлама Шаламова и Сергея Довлатова. Эти две черты позволяют рассматривать Прилепина как постмодерниста (Padsasonny 2018: 205-216).

Как мы уже сказали, сюжет романа Обители происходит в другой половине 1920-х гг. в лагере на Соловецких островах (север России) - Соловецком лагере особого назначения (СЛОН). СЛОН был одним из первых лагерей системы ГУЛага - его образовали в 1923 г. на территории бывшего монастыря и совхоза. Лагерники пользовались относительно большой свободой: в лагере существовали театр, музей, печатались газеты, а заключенные по политическим статьям могли создавать партийные фракции и вести полемику друг с другом. Положение лагерников изменилось в конце 20-х гг. Введенные тогда в СЛОНе реформы 
привели к значительному удешевлению содержания зеков и стали образцом для построения других лагерей и всей советской системы принудительного труда ${ }^{1}$ (Моруков).

С целью как можно верно восстановить реалии этого времени и места Захар Прилепин пользовался документами и свидетельствами бывших зеков. При этом автор попытался отобразить своеобразный язык ГУЛага. По мнению польского языковеда, Ярослава Пацулы, он состоял из нескольких составных частей (среди которых можно назвать язык лагерников и тюремный язык, а также деловой язык системы исправительно-трудовых лагерей), на которые большое влияние оказал уголовный сленг. Это было связано с составом зеков советских лагерей - рядом с заключенными по политическим делам, сроки отбывали профессиональные преступники - воры, убийцы, и т. д., которые часто находились выше в иерархии (Pacuła 2018: 60-64).

При переводе такой лексики стоит обратить внимание на разницу между фоновыми знаниями адресата текста оригинала и адресата переводного текста. Понятие «адресата» в этой статье рассматривается по мнению Романа Левицкого 2 : это представление переводчика о возможном читателе перевода (Lewicki 2017: 159). Знания поляка по теме советской пенитенциарной системы намного отличаются от знаний читателя текста оригинала. Исходя из того, что в пике деятельности советских лагерей заключенными были 2,5 млн человек, можно сказать, что лагерная жизнь стала для русских опытом общенационального масштаба - она имеет характер как постсоветского наследия, так и семейной памяти. Кроме того, эта тема широко описывалась многими писателями, о которых мы уже выше сказали, а также Александром Солженицыным, получателем Нобелевской премии по литературе именно за Архипелаг ГУЛАГ. Хотя поляки также были зеками лагерей, то не в таком количестве, которое позволило бы образоваться и закрепиться памяти о ГУЛаге в общепольском историческом наследии. Польский адресат, главным образом, реалии жизни в лагере может знать только благодаря произведениям вышеупомянутых А. И. Солженицына, В. Т. Шаламова, а также польского писателя Густава ХерлингаГрудзинского. Делая вывод, в отличие от русского адресата, польский «возможный читатель» мог не столкнуться с лагерным языком. Это вызывает

\footnotetext{
${ }^{1}$ О реформе труда в СЛОН, проведенной по предложению заключенного(!) Н. А. Френкеля, см. больше: Applebaum, A. Gutag, с. 58-64.

2 О других факторах, влияющих на проектирование переводчиком «адресата», см. больше: Lewicki, R. Zagadnienia lingwistyki przekładu. Lublin: Wydawnictwo Uniwersytetu Marii Curii-Skłodowskiej, 2017, c. 158172.
} 
трудности в переводе и заставляет переводчика применить разнообразные переводческие трансформации.

В тексте романа можно найти много названий лиц, принадлежащих к воровскому сленгу или происходящих из него, а также названия лиц из общелагерного жаргона. К первой группе относятся, главным образом, слова, которые называют представителей «воровского» мира, напр. блатной, а также называющие людей, несвязанных с миром профессиональных преступников, напр. фраер ‘1. человек, не имеющий отношения к воровской (преступной) среде' (Балдаев, Белко, Исупов 1992: 262).

В данной статье анализируются способы перевода названий лиц второй группы, к которой относятся, главным образом, названия лиц, определяющие людей по их политическим убеждениям, по их отношению к принудительному труду в лагере, а также называют их, используя статью уголовного кодекса, по которой были они осуждены.

Понятное русскому адресату слово каэр 'контрреволюционер, -/ка, -/ы, лицо, находящееся под следствием или осужденное за «контрреволюционное преступление»' (Росси 1987: 171) в переводе транскрибируется как kaer. При первом употреблении эта аббревиатура объяснается: «Najczęściej wybierał duchownego lub kaera, kontrrewolucjonistę» (Prilepin 2016: 34) (курсивы добалены автором статьи - А. Б.). Это было вызвано необходимостью обеспечнть полную передачу значения данного выражения в польском языке, так как польский читатель не смог бы ее самому расшифровать. В дальнейших примерах употребления слова kaer такое пояснение не используется. Более понятные польскому читателю названия членов политический партий дореволюционной России - эсдэки и эсерь - только транскрибируются, напр.: «Tamtego roku byli tu jeszcze polityczni - esdecy, eserowcy i inni anarchiści (...)» (Prilepin 2016: 34).

Русские слова беспризорный / беспризорник 'подросток, живущий на улице 3 в переводном тексте передаются с помощью транскрипции первого из них - bezprizorny - без никаких дополнительных пояснений. Такое решение обеспечивает передачу реалии, но при этом могло бы вызывать сомнения по поводу недолжной передачи значения. Эва Роевска-Олеярчук могла использовать такой прием, потому что значение термина объясняется характеристикой одного из персонажей, которым является ребенок около двенадцати лет.

\footnotetext{
3 «Массовое появление беспризорных восходит к годам гражданской войны 1918-21. Они образовали крупные, очень опасные банды» (Росси 1987: 29-30).
} 
Слово фитиль в значении 'человек, ослабевший от недоедания, болезней и непосильной работы' (Грачев 2003: 960) на польский язык переводится несколькими способами. Один из них - использование эквивалента с разговорным оттенком вместо сленгового, благодаря чему происходит частичная компенсация: «Здесь многие в первые же три месяца опускаются - либо становятся фитилями, либо идут в стукачи, либо попадают в услужение к блатным, и я даже не знаю, что хуже» (Прилепин 2019: 41) и «Wielu tutaj stacza się już po pierwszych trzech miesiącach - albo szybko się wykańczaja, albo zaczynają kapować, albo wysługują się błatnym - nie wiem, co gorsze» (Prilepin 2016: 36).

Второй способ - лексическая замена, как в следующем примере: «И мыкается, не затухая, искра Христова то в стукаче, то в фитиле, то в заключённом в карцер» (Прилепин 2019: 45) и «Ale iskra Chrystusowa nie gaśnie, tli się to $\mathrm{w}$ donosicielu, to $\mathrm{w}$ dogorywającym dochodiadze, to $\mathrm{w}$ więźniu karceru» (Prilepin 2016: 40). В вышеуказанном примере было использовано транскрибированное из русского языка слово dochodiaga (доходяга) с синонимическим к фитилю значением. Этот способ вполне объяснимый, так как Роевска-Олеярчук ссылается на фоновые знания польского адресата. Слово dochodiaga может быть понятно благодаря творчеству польского писателя Густава Херлинга-Грудзинского, роман которого Иной cвет описывает действительность советского лагеря. Передача значения фитиля обеспечена при помощи добавления определения dogorywajacy с переносным значением ‘теряющий силы, слабеющий'. Стоит отметить, что в произведении Прилепина также используется доходяга.

В дальнейших фрагментах текста используется также транскрипция fitil. Как в случае kaera, первое употребление слова fitil в польском тексте дополнительно объясняется с помощью переводческой сноски, которая ссылается на сведения польского адресата о как нацистской, так и советской системах концлагерей: «Fitil (ros. "knot"), inaczej dochodiaga - więzień, w którym życia zostało tyle, co płomienia w knocie; polski odpowiednik z czasów niemieckich obozów koncentracyjnych - muzułman» (Prilepin 2016: 52).

Слово филон 4 '1. симулянт, притворяющийся больным' (Грачев 2003: 958) чаще всего на польский язык переводится с помощью эквивалента с нейтральной окраской - symulant. Таким же образом переводится глагол филонить -

\footnotetext{
${ }^{4}$ Соловецкие заключенные придумали следующую, шутливую расшифровку слова филон: «Фиктивный Инвалид Лагерей Особого Назначения» (Росси 1987: 433).
} 
symulować. Однако не в каждом случае для перевода этой единицы используется нейтрализация стилистической окраски:

«-И убью, - ответил десятник и начал убивать: сшиб с ног, потоптал мужичку лицо, несколько раз вогнал сапог в бок, крича при этом: - Будешь работать, филон?» (Прилепин 2019: 75)

«I zabiję - odparł dziesiętnik i wprowadził słowa w czyn: powalił go na ziemię, deptał po twarzy, kilka razy kopnął w bok, krzycząc przy tym: - Będziesz pracować, nygusie?» (Prilepin 2016: 66).

В вышеприведенном примере в качестве эквивалента филона Э. РоевскаОлеярчук использовала слово nygus 'pot. pejorat. osoba, która nie lubi pracować i unika wszelkich działań wymagających wysiłku' (Wielki słownik języka polskiego). Оба слова имеют пренебрежительный характер. В польском тюремном жаргоне это слово также выступает. Оно имеет множество значений (также 'лентяй'), однако же главным образом оно используется со значением 'жертва преступления' (Stępniak, Podgórzec 1993: 344-345).

Похожим образом на польский язык переведено причастие филонящий: «Десятник вернулся неприметно, наверное, еще издалека приметил филонящего Ксиву (...)» (Прилепин 2019: 89) - «Dziesiętnik wrócił niepostrzeżenie, pewnie jeszcze z daleka zobaczył, że Ksywa bumeluje (...)» (Prilepin 2016: 78). Глагол bumelować 'pot. pejorat. osoba o lekceważącym stosunku do pracy, za którą otrzymuje wynagrodzenie, wykonująca ją niedbale lub nieprzychodząca do niej w wyznaczonym czasie' (Wielki słownik języka polskiego) частично восстанавливает реалии периода социализма, так как он часто использовался польской пропагандой времен Польской народной республики. Несмотря на изменение части речи, смысл выражения и отношение повествователя к персонажу полностью переданы.

Два слова, саморуб и самолом, мы рассмотрим вместе, так как в тексте романа они часто выступают рядом. Саморуб - это 'лицо, нанесшее себе увечье, чтобы избежать принудительного труда' (Росси 1987: 346) ${ }^{5}$; у самолома аналогичное значение. Эти слова переводятся двумя способами.

Первый из них - лексическая замена, которая была использована в следующих примерах: «Всем саморубам и самоломам положена смерть!» (Прилепин 2019: 91) - «Za samookaleczenie należy się czapa!» (Prilepin 2016: 80), а также «Летом саморуб - редкий случай, это зимой они гуртом идут (...)» (Прилепин 2019: 164) - «Latem samookaleczenie siekierą to rzadki przypadek, za to

\footnotetext{
${ }^{5}$ Об измемении отношения советской власти к саморубам - см. там же. 
zimą tacy idą hurtem (...)» (Prilepin 2016: 145). В обоих примерах название лица заменено названием действия - samookaleczenie, которое имеет нейтральный характер.

Саморуб и самолом как названия лиц передаются только с помощью описательного перевода: «Было еще несколько саморубов и самоломов, вроде Филиппа, и пара порезанных, но не добитых блатными» (Прилепин 2019: 148) «Było jeszcze kilku takich, co sami się okaleczyli, jak Filip, i paru pociętych przez błatnych, ale nie dobitych» (Prilepin 2016: 131). В отличие от вышеприведенного примера, в котором сленговое значение саморуба нейтрализуется, в следующей паре оно компенсируется с помощью разговорного оттенка эквивалента pochlastać: «Приехало соловецкое начальство на проверку, а он докладывает: сорок саморубов наказано отсекновением ушей! И его - к награде!» (Прилепин 2019: 164) - «Przyjechało sołowieckie naczalstwo na kontrolę, a on melduje: czterdziestu pochlastanych ukarano odcięciem uszu! I przedstawili go do nagrody!» (Prilepin 2016: 145).

В этом примере стоит обратить внимание на слово начальство и его эквивалент в переводе - naczalstwo. Польское соответствие было давно заимствовано из русского языка и имеет разговорную окраску. Тем способом компенсируются и восстанавливаются утраченные в других местах перевода названия реалий.

Перевод на польский язык общелагерных названий лиц осуществляется с помощью нескольких приемов. Одним из самых распространенных является транскрипция русских слов, напр. каэр - kaer, фитиль - fitil, беспризорныли bezprizorny. Иногда они дополнительно поясняются в тексте перевода. Второй способ перевода названий лиц - нейтрализация сленговой окраски, напр. филон symulant, или замена ее разговорной, напр. филон - nygus. Э. Роевска-Олеярчук использовала описательный перевод для передачи значений слов саморуб и самолом. С помощью лексической замены и использования заимствованных из русского языка слов она частично компенсировала утраченные названия реалий, напр. фитиль - dochodiaga, начальство - naczalstwo. Те же приемы использовались при переводе названий лиц, принадлежащих к уголовному сленгу. Главной целью Э. Роевской-Олеярчук было обеспечить как эквивалентность, так и адекватность текста перевода, т. е. приспособить его к польскому адресату. По нашему мнению, эта цель была полностью выполнена.

Еще многие языковые средства характеристики реалий советского лагеря в романе Захара Прилепина Обитель и их перевод не были проанализированы. 
К этой группе относятся способы компенсации утраченных в переводе названий реалий, общелагерные и уголовные слова и выражения, называющие предметы и действия (напр. мойка, базарить), а также язык пропаганды и официальный стиль речи администрации советских лагерей, сотрудников ОГПУ, и т. п.

\section{Summary}

The author concludes that the most common way of translating people's names coming from language created in Gulag system is transcription with footnotes, as well as using equivalents with colloquial or common features.

\section{Резюме}

Автор приходит к выводу, что большое количество единиц русского языка было переведено с помощью двух способов - транскрипции с пояснением или без, а также с помощью использования эквивалентов с разговорной стилистической окраской.

\section{Литература}

Балдаев, Д. С., Белко, В. К., Исупов, И. М. Словарь тюремно-лагерно-блатного жаргона (речевой и графический портрет советской тюрьмыl). Москва: Края Москвы, 1992.

Грачев, М. А. Словарь тысячелетнего русского арго. Москва: РИПОЛ КЛАССИК, 2003.

Прилепин, 3. Обитель. Москва: АСТ: Редакция Елены Шубиной, 2019.

Росси, Ж. Справочник по ГУЛагу. London: Overseas Publications Interchange Ltd., 1987.

Borkowska, А. Захар Прилепин - литературный портрет. Acta Universitatis Lodziensis. Folia Litteraria Rossica. 2019 (12), c. 121-130.

Lewicki, R. Zagadnienia lingwistyki przektadu. Lublin: Wydawnictwo Uniwersytetu Marii Curie-Skłodowskiej, 2017.

Pacuła, J. Polszczyzna w GUŁagu. Leksyka. Bielsko Biała: Wydawnictwo Naukowe Akademii Techniczno-Humanistyczna w Bielsku Białej, 2018. 
Padsasonny, S. Поэтика романа «Обитель» Захара Прилепина. Studia Rossica Gedanensia. 2018 (5), c. 200-217.

Prilepin, Z. Klasztor. Poznań: Czwarta Strona, 2016.

Stępniak, K., Podgórzec, Z. Słownik tajemnych gwar przestępczych. London: Puls, 1993.

\section{Интернет-источники}

Моруков, Ю. Н. Соловецкий лагерь особого назначения (1923-1933 гг.). Режим доступа: http://www.solovki.info/?action=archive\&id=219 (2020-04-28).

Официиальный сайт Захара Прилепина. Режим доступа: https://zaharprilepin.ru/ru /bio.html (2020-04-28).

Wielki słownik języka polskiego. Режим доступа: https://wsjp.pl/ (2020-04-28). 